\title{
Comparative studies for the biotechnological production of L-Lysine by immobilized cells of wild-type Corynebacterium glutamicum ATCC 13032 and mutant MH 20-22 B
}

\author{
Meerza Abdul Razak • Buddolla Viswanath
}

Received: 12 October 2014/ Accepted: 12 January 2015/Published online: 24 January 2015

(C) The Author(s) 2015. This article is published with open access at Springerlink.com

\begin{abstract}
Establishing a cost and time efficient approach for bioprocess optimization is desired but is challenging. In the present work, we have addressed the effectiveness of using immobilized cells for aerobic processes, behaviour of immobilized cells, optimization and upstream bioprocess analysis for the production of lysine by immobilized cells of Corynebacterium glutamicum ATCC 13032 and MH 20-22 B in stirred tank bioreactor. Optimized operational conditions for maximal yield and productivity were determined with six parameters i.e., $\mathrm{pH}$, temperature, fermentation time, airflow rate, glucose concentration and aeration rate. With the obtained results, it was evident that the optimum values for the upstream parameters viz., fermentation time, $\mathrm{pH}$, temperature, glucose concentration, air flow rate and agitation rate are $96 \mathrm{~h}, 7.5,30^{\circ} \mathrm{C}, 90 \mathrm{~g} / \mathrm{l}, 1.0$ vvm and $200 \mathrm{rpm}$ for both immobilized cells of $C$. glutamicum ATCC 13032 and MH 20-22 B. Immobilized cells of C. glutamicum MH 20-22 B, which is a leucine auxotroph has yielded more L-lysine compare to the immobilized cells of wild type strain C. glutamicum ATCC 13032.
\end{abstract}

Keywords L-Lysine production - C. glutamicum . Immobilization - Upstream bioprocess analysis

\footnotetext{
M. A. Razak

Natco Pharma Limited, Natco House, Road No. 2,

Banjara Hills, Hyderabad 500 034, India

B. Viswanath $(\bowtie)$

Department of Virology, Sri Venkateswara University,

Tirupati 517502, A. P, India

e-mail: buddolla@gmail.com
}

\section{Introduction}

Amino acids have been produced with the help of microorganisms for almost 50 years. The economic significance of these cellular building blocks is significant and hence demand is consistently growing and constant efforts to enhance production performance are directed towards the microorganisms, as well as towards technological improvements of the relevant processes. The L-glutamic acid is in first place of highest produced amino acid, followed by L-lysine and DL-methionine whereas the other amino acids follow behind (Anastassiadis 2007). The cause for the increased demand for amino acids stems from their consumption as food preservative, feed supplements, therapeutic agents and precursors for the production of peptides or agrochemicals (Leuchtenberger et al. 2005). L-lysine is essential as a feed additive for poultry and pig breeding.

Gram-positive, rod-shaped bacteria Corynebacterium glutamicum has usually occupied a special position within the amino acid producing microorganisms with industrial significance. The essential amino acid L-lysine is one of the most important amino acids applied as supplement in animal feed (Wendisch and Bott 2005; Bercovici and Fuller 2007). The supplementation of such feed materials with a lysine rich source leads to optimized growth of pigs or chicken (Wendisch and Bott 2005). The direct addition of lysine hereby has proven especially valuable. It does not cause an extra uptake and metabolization of other aminoacids beyond their requirement so that superfluous formation of ammonia and environmental burden by increased nitrogen loads in the manure is avoided. The progressing development of an increased utilization of white meat in different countries of the western as well as the eastern world has led to a vast market growth for lysine 
during the past decades (Tryfona and Bustard 2005). The high importance of lysine in nutrition has inspired intensive research on the lysine, bioprocess optimization, biosynthetic pathways and their regulation and the search for microorganisms capable of over-producing this amino acid. The first steps towards industrial production of lysine were done in Japan in the 1950s when Kyowa Hakko Co., Ltd., Tokyo initiated a research program targeted at finding a microorganim capable to produce glutamate. One of the results from this was the isolation of a microorganism Micrococcus glutamicus, later on renamed to C. glutamicum, which was able to produce glutamate (Kinoshita et al. 1957; Udaka 1960). During mutagenesis and screening program lysine producing mutants were discovered (Kinoshita et al. 1958) and the basis for lysine production was made. Within a few years the first industrial scale lysine manufacturing facility was developed. Since then lysine fermentation processes have been employed for large scale production. As the research interest for a cost effective production has increased, L-Lysine product prices have decreased. L-Lysine is produced by aerobic fermentation process using the bacterium $C$. glutamicum, it is an aerobic, non-sporulating, gram-positive, bacterium with GRAS (Generally Regarded As Safe) status that has been extensively used for the industrial production of a number of food grade amino acids, feed, and pharmaceutical products for many decades based on classical metabolic engineering. C. glutamicum abilities to produce other amino acids like L-threonine (Shiio 1990; Kase and Nakayama 1974; Shiio et al. 1991), L-methionine (Nakayama and Araki 1973; Kalinowski et al. 2003), L-serine (Eggeling 2007), L-histidine (Araki et al. 1974), L-valine (Ruklisha et al. 2007), L-tryptophan (Ikeda 2006), L-phenylalanine and L-tyrosine (Ikeda and Katsumata 1992), L-leucine (Patek 2007) and L-isoleucine (Guillout et al. 2002) has made it major work horse of industrial biotechnology. The biotechnological production of L-lysine by C. glutamicum requires a continuous improvement of the lysine production process with a special attention on optimization of the production process and strains engineering (Pfefferle et al. 2003). Therefore, the main objective of this paper is to analyze upstream bioprocess and comparative studies of L-Lysine production by free cells of Corynebacterium glutamicum ATCC 13032 and MH 20-22 B in stirred tank bioreactor.

\section{Materials and methods}

The wild-type C. glutamicum ATCC 13032 was acquired from American Type and Culture Collection, Manassas, USA and C. glutamicum MH 20-22 B was donated by Professor Eggeling, Biotechnology Institute, Julich, Germany.
Both these strains were cultured on agar slopes containing peptone $(5 \mathrm{~g})$, beef extract $(3 \mathrm{~g}), \mathrm{NaCl}(5 \mathrm{~g})$, agar $(15 \mathrm{~g})$, distilled water $(1,000 \mathrm{ml})$ was maintained at $\mathrm{pH} 7$.

\section{Immobilization method}

Growth medium composition

The composition of growth medium is as follows: Glucose $(2 \mathrm{~g})$, beef extract $(1 \mathrm{~g})$, bacto peptone $(1 \mathrm{~g}), \mathrm{NaCl}$ $(0.25 \mathrm{~g})$, agar $(2 \mathrm{~g})$, distilled water $(100 \mathrm{ml})$ and the $\mathrm{pH} 7$.

Agar slants of $C$. glutamicum cells which were grown for $24 \mathrm{~h}$ were used to inoculate $50 \mathrm{ml}$ of growth media and kept on shaker for $48 \mathrm{~h}(150 \mathrm{rpm})$ at $30^{\circ} \mathrm{C}$. Hundred milliliter of $72 \mathrm{~h}$ culture was used to prepare immobilized beads of calcium alginate. Fifteen percent volume of beads were employed throughout this study.

Immobilization of $C$. glutamicum cells was done in strict aseptic conditions. Gluteraldehyde entrapment method using cross linked calcium alginate was used to immobilize C. glutamicum cells (Jetty et al. 2005; Marek et al. 1985). Hundred microliter gluteraldehyde and $3 \%$ sodium alginate were thoroughly mixed with $0.06 \%$ cells on dry cell weight basis (DCW) (w/v), to get uniform suspension. This uniform suspension was transferred into $0.2 \mathrm{M} \mathrm{CaCl}_{2}$ solution using peristaltic pump through a cut micropipette tip (or) orifice. The curing of the formed beads was done by incubating in $0.2 \mathrm{M} \mathrm{CaCl}_{2}$ solution for $24 \mathrm{~h}$ and washed twice with sterile saline solution [0.9\% $\mathrm{NaCl}$ solution (w/v)] and preserved at $4{ }^{\circ} \mathrm{C}$ in saline solution for further use. The above immobilization method is followed for both strains of C. gluatamicum to get immobilized cells of them.

\section{Fermentation procedure for lysine production by immobilized cells of $C$. glutamicum ATCC 13032 and MH 20-22 B}

Batch or fed-batch processes are employed for the commercial production of amino acids. In batch operations all of the nutrients are added at the beginning. And moreover in batch fermentations microorganisms grows until one or more of essential nutrients get exhausted or until fermentation conditions like oxygen limitation, $\mathrm{pH}$ decrease and product inhibition become unfavourable. In the present work fermentation experiments with immobilized cells have been conducted in batch mode using a sterilized stirred tank bioreactor. The immobilized $C$. glutamicum cells were used to inoculate the fermentation medium in the bioreactor and this batch fermentation was carried out for $200 \mathrm{~h}$. The above batch fermentation procedure was 
carried out at different parameters separately for immobilized cells of both strains, to optimize the upstream parameters. New Brunswick Bioreactor of $5 \mathrm{~L}$ was used for the present batch fermentation experiments and was carried out for $120 \mathrm{~h}$. Initially all reactor parts are separated. All parts are washed with distilled water thoroughly and again with acetone before sterilization. After washing with distilled water all the above parts are wrapped with aluminium foil before placing into the autoclave. All these accessories are kept in the autoclave and the autoclave is operated at a temperature of $120^{\circ} \mathrm{C}$ and a pressure of 15 psi for a period of $20 \mathrm{~min}$. The aeration rate for the batch fermentation was set to different vvm by the integrated gas flow controller. A $\mathrm{pH}$ electrode (Mettler Toledo, Giessen, Germany) and automated addition of $25 \% \mathrm{NH}_{4} \mathrm{OH}$ was used to maintain the $\mathrm{pH}$ at 7 in the stirred tank bioreactor. The added volume was determined gravimetrically (Lab Balance Cupis, Sartorius, Gottingen, Germany). Dissolved oxygen was determined using a pO2 (partial pressures of oxygen) electrode (Mettler Toledo, Giessen, Germany) and by variation of the stirrer speed. This was controlled by the process control software Base Lab (BASFSE, Ludwigshafen, Germany).Temperature was maintained at $30{ }^{\circ} \mathrm{C}$ using jacket cooling. $\mathrm{CO}_{2}$ and $\mathrm{O}_{2}$ in the exhaust gas were analyzed by a mass spectrometer. All processes data were monitored online and recorded by BaseLab. The composition of media used for fermentation process in this work is as follow:

$\mathrm{CaCl}_{2} 2 \mathrm{H}_{2} \mathrm{O}(1 \mathrm{~g}),\left(\mathrm{NH}_{4}\right) 2 \mathrm{SO}_{4}(30 \mathrm{~g}), \mathrm{MgSO}_{4} 7 \mathrm{H}_{2} \mathrm{O}$ $(0.4 \mathrm{~g}), \mathrm{NaCl}(0.05 \mathrm{~g}), \mathrm{MnSO}_{4} \mathrm{H}_{2} \mathrm{O}(0.0076 \mathrm{~g}), \mathrm{FeSO}_{4}$ $7 \mathrm{H}_{2} \mathrm{O}(0.001 \mathrm{~g}), \mathrm{KH}_{2} \mathrm{PO}_{4}(1 \mathrm{~g}), \mathrm{K}_{2} \mathrm{HPO}_{4}(1 \mathrm{~g})$, Urea $(2 \mathrm{~g})$, Yeast extract (1.5 g), Peptone ( $\mathrm{g})$, D-Glucose (150 g), Thiamine $(0.2 \mathrm{mg})$, D-Biotin $(0.5 \mathrm{mg})$, L-Serine $(0.1 \mathrm{mg})$ and distilled water $(1.0 \mathrm{~L})$. And the $\mathrm{pH}$ was maintained at 7.0.

\section{Analytical estimation of L-lysine and substrates}

Cell concentration was determined photometrically at $660 \mathrm{~nm}$ (UV-Visible spectrophotometer, Thermo Electron Corporation). Supernatant from batch fermentation was used for quantification of substrates and products which were obtained by separation of the biomass by centrifugation at $8,500 \mathrm{~g}$ for $5 \mathrm{~min}$ at $4{ }^{\circ} \mathrm{C}$. L-lysine was estimated by the method of Chinard (Chinard 1952). Glucose concentration was determined by anthrone method (Morris 1948; Neish 1952). Residual sugar was determined as glucose in the supernatant fluid by the colorimetric DNS Method (Miller 1959). Biomass in the broth was estimated in $1 \mathrm{ml}$ of the sample by centrifugation, and dried in an oven at $105^{\circ} \mathrm{C}$ until constant cell weight obtained.

\section{Results and discussion}

Earlier we have carried out many batch fermentations to improve the production rate of L-Lysine by free and immobilized cells of $C$. glutamicum under various process conditions. It was reported from one of our former investigation that L-Lysine can be produced more efficiently by immobilized growing $C$. glutamicum cells compared to free cells in stirred tank bioreactor (Razak and viswanath 2014). In addition, many investigators have stated about the multistage continuous fermentation processes and their difficulties to run continuous L-Lysine production systems (Becker 1982; Michalski et al. 1984). So in the present investigation we have focused on the upstream bioprocess analysis, comparative studies and optimization of L-Lysine production by immobilized cells of wild type $C$. glutamicum ATCC 13032 and C.glutamicum mutant MH 20-22 B.

\section{Effect of fermentation time on L-lysine production by immobilized cells of $C$. glutamicum ATCC 13032 and MH 20-22 B}

The investigation on effect of fermentation time on L-lysine production by immobilized cells of Corynebacterium glutamicum ATCC 13032 and MH 20-22 B cells was carried out under operating fermentation conditions like temperature $28^{\circ} \mathrm{C}, \mathrm{pH} 7.0$, air flow rate $1.5 \mathrm{vvm}$, agitation rate of $300 \mathrm{rpm}$ and glucose concentaration of $100(\mathrm{~g} / \mathrm{l})$. It is observed that as a fermentation time increases the concentration of the residual glucose decreases between 40 and $120 \mathrm{~h}$. Similar type of studies was carried out by Amin and Al-Talhi for production of L-Glutamic acid by using immobilized cells of $C$. glutamicum (Amin and Al-Talhi 2007). L-lysine concentration was relatively lower for the first $70 \mathrm{~h}$ and the cell were multiplied with rapid growth of biomass. As the fermentation proceeds the glucose consumption and L-lysine production increased at $96 \mathrm{~h}$ with high sugar utilization and maximum L-lysine concentration. After $96 \mathrm{~h}$, maximum product achieved a downward trend, L-lysine concentration and yields were found to be decreased; in-spite of an increase in fermentation time due to depletion of nutrients. Figure 1 results describe that the maximum lysine concentration is $22.83 \pm 0.21 \mathrm{~g} / \mathrm{l}$ and biomass concentration is $14.26 \pm 0.18 \mathrm{~g} / 1$ at $96 \mathrm{~h}$ for C. glutamicum ATCC 13032 immobilized cells.

The results presented in the Fig. 2 shows that L-lysine production was more at $96 \mathrm{~h}$, it is the best fermentation time for the production of L-lysine by immobilized cells of C. glutamicum MH 20-22 B. The maximal yield of the L-lysine by immobilized cells of $C$. glutamicum MH 20-22 $\mathrm{B}$ at $96 \mathrm{~h}$ is $23.44 \pm 0.27 \mathrm{~g} / \mathrm{l}$ and biomass concentration is $15.28 \pm 0.22 \mathrm{~g} / \mathrm{l}$ The results presented in the Figs. 1 and 2 
Fig. 1 Effect of fermentation time on L-lysine production by immobilized cells of $C$. glutamicum ATCC 13032
Fig. 2 Effect of fermentation time on L-lysine production by immobilized cells of $C$. glutamicum MH 20-22 B
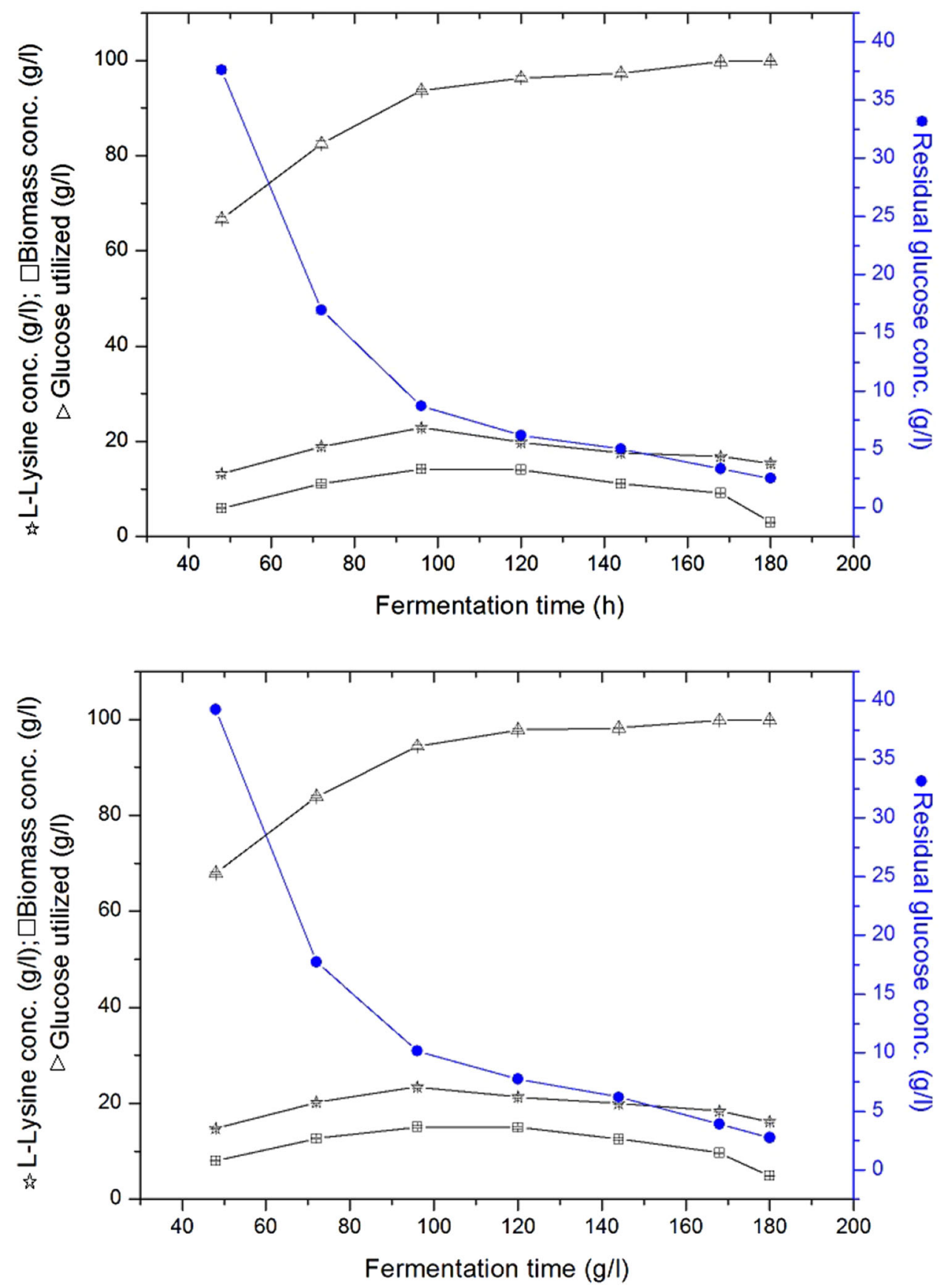

shows that L-lysine production was good at $96 \mathrm{~h}$, which is the best fermentation time for the production of L-lysine by immobilized cells of C. glutamicum MH 20-22 B.

\section{Effect of temperature on L-lysine production} by immobilized cells of $C$. glutamicum ATCC 13032 and MH 20-22 B

The growth rate of bacterial microorganism is basically dependent on temperature during fermentation which makes changes in whole metabolism. Any change in the temperature can alter the substrate utilization rate of microorganism which leads to unbalanced nutrients in the medium with respect to growth rate of the $C$. glutamicum cells. If any of the crucial nutrients is exhausted soon or unused this can make the culture from balanced to unbalanced growth and results in its performance change. The effect of temperature on L-Lysine production by immobilized cells of $C$. glutamicum ATCC 13032 and MH 20-22 B was studied under different operating conditions like fermentation time of $96 \mathrm{~h}, \mathrm{pH}$ of 7.0, air flow rate of $1.5 \mathrm{vvm}$, 
Table 1 Effect of temperature on L-lysine production by immobilized cells of $C$. glutamicum ATCC 13032

\begin{tabular}{llllll}
\hline S1. no. & $\begin{array}{l}\text { Temperature } \\
\left({ }^{\circ} \mathrm{C}\right)\end{array}$ & $\begin{array}{l}\text { Lysine conc. } \\
(\mathrm{p})(\mathrm{g} / \mathrm{l})\end{array}$ & $\begin{array}{l}\text { Biomass } \\
(\mathrm{x})(\mathrm{g} / \mathrm{l})\end{array}$ & $\begin{array}{l}\text { Residual glucose } \\
\text { conc. }(\mathrm{g} / \mathrm{l})\end{array}$ & $\begin{array}{l}\text { Glucose utilized } \\
(\mathrm{s})(\mathrm{g} / \mathrm{l})\end{array}$ \\
\hline 1 & 27 & 16.78 & 13.49 & 11.12 & 92.55 \\
2 & 28 & 20.22 & 15.67 & 7.85 & 95.88 \\
3 & 29 & 21.91 & 16.00 & 7.95 & 96.77 \\
4 & 30 & 23.03 & 18.34 & 6.17 & 98.44 \\
5 & 31 & 22.56 & 17.98 & 3.48 & 97.65 \\
6 & 32 & 19.87 & 15.90 & 2.19 & 95.48 \\
\hline
\end{tabular}

Table 2 Effect of temperature on L-lysine production by immobilized cells of $C$. glutamicum $\mathrm{MH}$ 20-22 B

\begin{tabular}{llllll}
\hline Sl. no. & $\begin{array}{l}\text { Temperature } \\
\left({ }^{\circ} \mathrm{C}\right)\end{array}$ & $\begin{array}{l}\text { Lysine conc. } \\
(\mathrm{p})(\mathrm{g} / \mathrm{l})\end{array}$ & $\begin{array}{l}\text { Biomass } \\
(\mathrm{x})(\mathrm{g} / \mathrm{l})\end{array}$ & $\begin{array}{l}\text { Residual glucose } \\
\text { conc. }(\mathrm{g} / \mathrm{l})\end{array}$ & $\begin{array}{l}\text { Glucose utilized } \\
(\mathrm{s})(\mathrm{g} / \mathrm{l})\end{array}$ \\
\hline 1 & 27 & 17.89 & 15.15 & 12.33 & 89.76 \\
2 & 28 & 21.74 & 15.99 & 9.64 & 92.45 \\
3 & 29 & 22.33 & 16.79 & 8.61 & 93.48 \\
4 & 30 & 24.45 & 19.45 & 6.42 & 95.67 \\
5 & 31 & 23.05 & 18.82 & 4.66 & 97.43 \\
6 & 32 & 21.74 & 16.44 & 2.68 & 99.41 \\
\hline
\end{tabular}

agitation rate of $300 \mathrm{rpm}$ and glucose concentration of $100 \mathrm{~g} / \mathrm{l}$. Glucose utilization was high at $30^{\circ} \mathrm{C}$. The down trend of residual glucose as the temperature increases can be seen after $30{ }^{\circ} \mathrm{C}$ the L-lysine biomass concentration was decreased. It was observed that $C$. glutamicum ATCC 13032 immobilized cells had shown maximum L-lysine concentration of $23.03 \pm 0.17 \quad(\mathrm{~g} / \mathrm{l})$ along with $18.34 \pm 0.18 \mathrm{~g} / \mathrm{l}$ of maximum biomass production at $30{ }^{\circ} \mathrm{C}$ (Table 1). Hilliger et al. (1984) observed temperature as one of the key fermentation parameters which has good influence on growth and L-Lysine formation by C. glutamicum (Hilliger et al. 1984). An increase in temperature resulted in decreased productivity, which suggested that a little increase in temperature has profound effect on cellular activities, which might be because of repression of metabolic enzymes. C. glutamicum $\mathrm{MH}$ 20-22 B immobilized cells shows maximum L-lysine production of $24.45 \pm 0.19(\mathrm{~g} / \mathrm{l})$ and biomass concentration $19.46 \pm 0.18(\mathrm{~g} / \mathrm{l})$ at $30{ }^{\circ} \mathrm{C}$ (Table 2). The production of $\mathrm{L}-$ Lysine by immobilized cells of C. glutamicum MH 20-22 B is more when compared with C. glutamicum ATCC 13032 immobilized cells.

\section{Effect of pH on L-lysine production by immobilized cells C. glutamicum ATCC 13032 and MH 20-22 B}

The $\mathrm{pH}$ is very important process parameter strongly influences the microbial fermentation. In fermentation process the $\mathrm{pH}$ of the broth decreases due to accumulation of other byproducts. As a result the bacterial growth was cease with affiliated decrease in the yield. Basic compounds such as sodium hydroxide, potassium hydroxide, ammonium hydroxide, calcium carbonate, urea, ammonia and inorganic acid compounds such as phosphoric sulphuric acid are used in controlling $\mathrm{pH}$ in L-lysine producing cultures ranging from 5.0 to 8.0. The effect of $\mathrm{pH}$ on L-lysine yield was found to be very major and crucial parameter. In the present study, effect of $\mathrm{pH}$ on L-lysine production was carried out at the fermentation time of $96 \mathrm{~h}$, temperature of $30^{\circ} \mathrm{C}$, air flow rate of 1.5 vvm, agitation rate of $300 \mathrm{rpm}$ and glucose concentration rate of $100 \mathrm{~g} / \mathrm{l}$. Figures 1 and 2 shows the effect of $\mathrm{pH}$ on L-Lysine production by immobilized cells of $C$. glutamicum ATCC 13032 and MH 20-22 B. pH of the fermentation processes can also be maintained by adding ammonia water along with small amount of $\mathrm{CaCO}_{3}$. (Wang et al. 1991). The optimum $\mathrm{pH}$ for C. glutamicum ATCC 13032 immbolized cells is 7.5 at which the maximum lysine concentration of $23.98 \pm 0.15(\mathrm{~g} / \mathrm{l})$ and biomass concentrarion of $19.19 \pm 0.15 \quad(\mathrm{~g} / \mathrm{l})$ was observed (Table 3). To maintain optimum $\mathrm{pH}$, reagents like calcium carbonate must be added to the culture medium at the beginning of the fermentation, thus calcium carbonate was used as internal neutralizing agent. The maximum L-lysine concentration of $C$. glutamicum MH 20-22 B immobilized cells is $25.63 \pm 0.18(\mathrm{~g} / \mathrm{l})$ and biomass concentration is $20.43 \pm 0.21(\mathrm{~g} / \mathrm{l})$, it was obtained at $7.5 \mathrm{pH}$ (Table 4). Above results prove that $7.5 \mathrm{pH}$ is the best suited for more lysine production by immobilized cells of C. glutamicum ATCC 13032 and MH 20-22 B. 
Table 3 Effect of $\mathrm{pH}$ on L-Lysine production by immobilized cells of $C$. glutamicum ATCC 13032

\begin{tabular}{llllll}
\hline Sl. no. & $\mathrm{pH}$ & $\begin{array}{l}\text { Lysine conc. } \\
(\mathrm{p})(\mathrm{g} / \mathrm{l})\end{array}$ & $\begin{array}{l}\text { Biomass } \\
(\mathrm{x})(\mathrm{g} / \mathrm{l})\end{array}$ & $\begin{array}{l}\text { Residual glucose } \\
\text { conc. }(\mathrm{g} / \mathrm{l})\end{array}$ & $\begin{array}{l}\text { Glucose utilized } \\
(\mathrm{s})(\mathrm{g} / \mathrm{l})\end{array}$ \\
\hline 1 & 6 & 13.16 & 13.33 & 11.93 & 92.02 \\
2 & 6.5 & 18.73 & 17.29 & 9.32 & 95.64 \\
3 & 7 & 20.91 & 18.66 & 6.10 & 98.65 \\
4 & 7.5 & 23.98 & 19.19 & 4.79 & 99.72 \\
5 & 8 & 20.19 & 16.59 & 3.89 & 97.08 \\
6 & 8.5 & 18.70 & 14.40 & 2.59 & 96.65 \\
\hline
\end{tabular}

\begin{tabular}{llllll}
\hline Sl. no. & $\mathrm{pH}$ & $\begin{array}{l}\text { Lysine conc. } \\
(\mathrm{p})(\mathrm{g} / \mathrm{l})\end{array}$ & $\begin{array}{l}\text { Biomass } \\
(\mathrm{x})(\mathrm{g} / \mathrm{l})\end{array}$ & $\begin{array}{l}\text { Residual glucose } \\
\text { conc. }(\mathrm{g} / \mathrm{l})\end{array}$ & $\begin{array}{l}\text { Glucose utilized } \\
(\mathrm{s})(\mathrm{g} / \mathrm{l})\end{array}$ \\
\hline 1 & 6 & 14.69 & 15.47 & 12.86 & 89.23 \\
2 & 6.5 & 19.9 & 18.68 & 10.44 & 91.65 \\
3 & 7 & 21.78 & 19.33 & 7.34 & 94.75 \\
4 & 7.5 & 25.62 & 20.42 & 5.60 & 96.49 \\
5 & 8 & 21.71 & 17.53 & 4.41 & 97.68 \\
6 & 8.5 & 19.7 & 15.62 & 2.68 & 99.41 \\
\hline
\end{tabular}

Table 4 Effect of $\mathrm{pH}$ on L-lysine production by immobilized cells of $C$. glutamicum $\mathrm{MH}$ 20-22 B different ranges of glucose concentrations are 70, 80, 90, 100, 110 and 120 (g/l). From running different batches, it was clearly confirmed and concluded that lysine production is cell-growth associated and the growth of the cells is influenced by glucose concentration. The immobilized cells of $C$. glutamicum ATCC 13032 grown at $90 \mathrm{~g} / \mathrm{l}$. of glucose concentration have produced maximum lysine with $25.42 \pm 0.23 \quad(\mathrm{~g} / \mathrm{l})$ and biomass concentration of $18.34 \pm 0.14(\mathrm{~g} / \mathrm{l})$. Glucose concentration on L-lysine production was investigated by Hirose and Shibai (1985). and it was described that higher concentration of glucose inhibited bacterial growth along with low yield Hirose and Shibai 1985. Effect of glucose concentration on L-lysine production by immobilized cells of $C$. glutamicum ATCC is summarized in Table 5. Table 6 clearly illustrates that lysine produced by $C$. glutamicum $\mathrm{MH}$ 20-22 B immoblized cells is $26.60 \pm 0.17(\mathrm{~g} / \mathrm{l})$ and biomass concentration is of $19.68 \pm 0.11$ at glucose concentration of $90 \mathrm{~g} / \mathrm{l}$. As the glucose concentration is increased simultaneously biomass concentration is also increased. It was also seen in
Table 5 Effect of glucose concentration on L-lysine production by immobilized cells of C. glutamicum ATCC 13032

\begin{tabular}{llllll}
\hline S1. no. & $\begin{array}{l}\text { Glucose } \\
\text { concentration }(\mathrm{g} / \mathrm{l})\end{array}$ & $\begin{array}{l}\text { Lysine conc. } \\
(\mathrm{p})(\mathrm{g} / \mathrm{l})\end{array}$ & $\begin{array}{l}\text { Biomass } \\
(\mathrm{x})(\mathrm{g} / \mathrm{l})\end{array}$ & $\begin{array}{l}\text { Residual glucose } \\
\text { conc. }(\mathrm{g} / \mathrm{l})\end{array}$ & $\begin{array}{l}\text { Glucose utilized } \\
(\mathrm{s})(\mathrm{g} / \mathrm{l})\end{array}$ \\
\hline 1 & 70 & 16.59 & 5.37 & 3.97 & 67.74 \\
2 & 80 & 20.11 & 10.76 & 5.93 & 76.55 \\
3 & 90 & 25.42 & 18.34 & 6.22 & 84.92 \\
4 & 100 & 22.21 & 17.91 & 10.61 & 90.25 \\
5 & 110 & 19.07 & 16.60 & 15.49 & 96.54 \\
6 & 120 & 15.99 & 15.05 & 18.98 & 97.48 \\
\hline
\end{tabular}


Table 6 Effect of glucose concentration on L-lysine production by immobilized cells of C. glutamicum MH 20-22 B

\begin{tabular}{llllll}
\hline S1. no. & $\begin{array}{l}\text { Substrate } \\
\text { conc. }(\mathrm{g} / \mathrm{l})\end{array}$ & $\begin{array}{l}\text { Lysine conc. } \\
(\mathrm{p})(\mathrm{g} / \mathrm{l})\end{array}$ & $\begin{array}{l}\text { Biomass } \\
(\mathrm{x})(\mathrm{g} / \mathrm{l})\end{array}$ & $\begin{array}{l}\text { Residual glucose } \\
\text { conc. }(\mathrm{g} / \mathrm{l})\end{array}$ & $\begin{array}{l}\text { Glucose utilized } \\
(\mathrm{s})(\mathrm{g} / \mathrm{l})\end{array}$ \\
\hline 1 & 70 & 18.5 & 7.93 & 4.61 & 67.48 \\
2 & 80 & 21.10 & 11.38 & 6.66 & 75.43 \\
3 & 90 & 26.59 & 19.68 & 7.47 & 84.62 \\
4 & 100 & 23.7 & 18.64 & 12.33 & 89.76 \\
5 & 110 & 20.10 & 17.46 & 16.85 & 97.24 \\
6 & 120 & 17.5 & 16.64 & 20.66 & 99.34 \\
\hline
\end{tabular}

Table 7 Effect of airflow rate on L-lysine production by immobilized cells of $C$. glutamicum ATCC 13032

\begin{tabular}{llllll}
\hline Sl. no. & $\begin{array}{l}\text { Air flow rate } \\
(\mathrm{vvm})\end{array}$ & $\begin{array}{l}\text { Lysine conc. } \\
(\mathrm{p})(\mathrm{g} / \mathrm{l})\end{array}$ & $\begin{array}{l}\text { Biomass } \\
(\mathrm{x})(\mathrm{g} / \mathrm{l})\end{array}$ & $\begin{array}{l}\text { Residual glucose } \\
\text { conc. }(\mathrm{g} / \mathrm{l})\end{array}$ & $\begin{array}{l}\text { Glucose utilized } \\
(\mathrm{s})(\mathrm{g} / \mathrm{l})\end{array}$ \\
\hline 1 & 0.25 & 14.37 & 9.94 & 10.68 & 76.23 \\
2 & 0.5 & 17.97 & 13.17 & 9.11 & 79.34 \\
3 & 0.75 & 20.13 & 18.07 & 5.69 & 84.32 \\
4 & 1 & 25.21 & 19.11 & 4.87 & 85.56 \\
5 & 1.25 & 24.12 & 16.54 & 3.04 & 87.34 \\
6 & 1.5 & 23.41 & 14.76 & 2.79 & 87.00 \\
\hline
\end{tabular}

the present experiments any excessive substrate concentration present in the fermentation broth leads to decrease in the product concentration. Hadj Sassi et al. (1988) reported that the early concentration of glucose have impact on the production of L-lysine by Corynebacterium $\mathrm{Sp}$. in batch culture and found that the specific production rate was obtained at or above $65 \mathrm{~g} / 1$ of glucose (Hadj Sassi et al. 1988). It was also observed that $\mathrm{pH}$ and substrate concentration has significant effect in comparison to temperature.

\section{Effect of airflow rate on L-lysine production by immobilized cells of $C$. glutamicum ATCC 13032 and MH 20-22 B}

In submerged cultures, the oxygen availability influences microbial production of amino acids. Therefore the oxygen plays crucial task in regulation of both intermediately metabolism and biomass formation coupled with alteration of L-lysine synthesis. If excess of oxygen is supplied, it may lead to formation of other metabolites like succinic acids and lactic acid. While the low availability of oxygen decrease the targeted product production. To investigate the optimum value of air flow rate for immobilized cells of C. glutamicum ATCC 13032 and MH 20-22 B experimental studies were conducted in a stirred tank bioreactor under conditions $\mathrm{pH} 7.5$, fermentation time of $96 \mathrm{~h}$, temperature $30{ }^{\circ} \mathrm{C}$, agitation rate of $300 \mathrm{rpm}$, glucose concentration of $90 \mathrm{~g} / \mathrm{l}$ and the aeration rate was maintained at different ranges from 0.25 to 1.5 . Tables 7 and 8 showed the characteristics batches of L-lysine fermentation at a range of $0.25-1.5$ volume air per volume of medium per minute (vvm). The best air flow rate for L-lysine production by $C$. glutamicum ATCC 13032 immobilized cells is 1.0 vvm at which the lysine concentration is $25.21 \pm 0.15 \mathrm{~g} / \mathrm{l}$ and the biomass productivity was is $19.11 \pm 0.19(\mathrm{~g} / \mathrm{l})$ (Table 7). Glucose utililized was $85.56 \pm 0.27 \mathrm{~g} / \mathrm{l}$ at 1.0 vvm. So $1.0 \mathrm{vvm}$ was considered as the optimum airflow rate for C. glutamicum ATCC 13032. Wang et al. (1991) worked at $200 \mathrm{rpm}$ for fermentation of L-lysine on rotary shaker and suggested optimum air flow rate of L-lysine production is $1.0 \mathrm{vvm}$ or above $1.0 \mathrm{vvm}$ approximately. Table 8 states that maximum lysine production is $26.82 \pm 0.17(\mathrm{~g} / \mathrm{l})$, biomass concentration is $20.93 \pm 0.20$ $(\mathrm{g} / \mathrm{l})$ and glucose utililized is $86.48 \pm 0.35(\mathrm{~g} / \mathrm{l})$ for $C$. glutamicum MH 20-22 B immobilized cells. Maximum product concentration, biomass and glucose utilized are good at the air flow rate of $1.0 \mathrm{vvm}$. Therefore optimum air flow rate for L-lysine production by $C$. glutamicum $\mathrm{MH}$ 20-22 B immobilized cells is found to be $1.0 \mathrm{vvm}$.

\section{Effect of agitation rate on L-lysine production by immobilized cells of $C$. glutamicum ATCC 13032 and MH 20-22 B}

In bioreactor, fermentation medium was agitated to provide homogeneity across the vessel. Agitation and aeration in a stirred tank bioreactor always causes foaming. Excess foaming drives the broth out of the bioreactor and contaminates the system rapidly. So optimum aeration and 
Table 8 Effect of airflow rate on L-lysine production by immobilized cells of

C. glutamicum MH 20-22 B

\begin{tabular}{llllll}
\hline S1. no. & $\begin{array}{l}\text { Aeration rate } \\
(\mathrm{vvm})\end{array}$ & $\begin{array}{l}\text { Lysine conc. } \\
(\mathrm{p})(\mathrm{g} / \mathrm{l})\end{array}$ & $\begin{array}{l}\text { Biomass } \\
(\mathrm{x})(\mathrm{g} / \mathrm{l})\end{array}$ & $\begin{array}{l}\text { Residual glucose } \\
\text { conc. }(\mathrm{g} / \mathrm{l})\end{array}$ & $\begin{array}{l}\text { Glucose utilized } \\
(\mathrm{s})(\mathrm{g} / \mathrm{l})\end{array}$ \\
\hline 1 & 0.25 & 16.97 & 11.39 & 12.41 & 78.68 \\
2 & 0.5 & 19.68 & 14.95 & 10.35 & 81.56 \\
3 & 0.75 & 21.56 & 19.09 & 6.96 & 85.04 \\
4 & 1 & 26.85 & 20.93 & 5.26 & 86.47 \\
5 & 1.25 & 25.97 & 18.37 & 3.53 & 88.56 \\
6 & 1.5 & 24.44 & 16.78 & 3.02 & 88.97 \\
\hline
\end{tabular}

Table 9 Effect of agitation rate on L-lysine production by by immobilized cells of C. glutamicum ATCC 13032

Table 10 Effect of agitation rate on L-lysine production by by immobilized cells of C. glutamicum $\mathrm{MH} 20-22 \mathrm{~B}$

\begin{tabular}{llllll}
\hline Sl. no. & $\begin{array}{l}\text { Agitation rate } \\
(\mathrm{rpm})\end{array}$ & $\begin{array}{l}\text { Lysine conc. } \\
(\mathrm{p})(\mathrm{g} / \mathrm{l})\end{array}$ & $\begin{array}{l}\text { Biomass } \\
(\mathrm{x})(\mathrm{g} / \mathrm{l})\end{array}$ & $\begin{array}{l}\text { Residual glucose } \\
\text { conc. }(\mathrm{g} / \mathrm{l})\end{array}$ & $\begin{array}{l}\text { Glucose utilized } \\
(\mathrm{s})(\mathrm{g} / \mathrm{l})\end{array}$ \\
\hline 1 & 100 & 21.45 & 11.87 & 9.37 & 93.55 \\
2 & 150 & 25.10 & 14.54 & 7.19 & 94.95 \\
3 & 200 & 30.17 & 16.97 & 3.99 & 96.68 \\
4 & 250 & 27.32 & 15.11 & 6.14 & 97.35 \\
5 & 300 & 25.98 & 16.40 & 5.43 & 98.85 \\
6 & 350 & 23.41 & 15.31 & 8.97 & 97.16 \\
7 & 400 & 22.72 & 13.96 & 10.20 & 95.33 \\
\hline
\end{tabular}

\begin{tabular}{llllll}
\hline Sl. no. & $\begin{array}{l}\text { Agitation rate } \\
(\mathrm{rpm})\end{array}$ & $\begin{array}{l}\text { Lysine conc. } \\
(\mathrm{p})(\mathrm{g} / \mathrm{l})\end{array}$ & $\begin{array}{l}\text { Biomass } \\
(\mathrm{x})(\mathrm{g} / \mathrm{l})\end{array}$ & $\begin{array}{l}\text { Residual glucose } \\
\text { conc. }(\mathrm{g} / \mathrm{l})\end{array}$ & $\begin{array}{l}\text { Glucose utilized } \\
(\mathrm{s})(\mathrm{g} / \mathrm{l})\end{array}$ \\
\hline 1 & 100 & 23.63 & 13.45 & 10.22 & 80.87 \\
2 & 150 & 26.09 & 15.79 & 8.41 & 83.65 \\
3 & 200 & 31.58 & 17.72 & 4.07 & 86.03 \\
4 & 250 & 28.49 & 16.77 & 7.48 & 84.16 \\
5 & 300 & 27.94 & 17.39 & 6.82 & 83.27 \\
6 & 350 & 25.78 & 16.94 & 10.67 & 81.42 \\
7 & 400 & 23.33 & 15.09 & 11.45 & 80.64 \\
\hline
\end{tabular}

agitation must be operated which minimizes foaming and maximizes the lysine production rate. L-lysine production at different agitation rates of 100, 150, 200, 300, 350, $400 \mathrm{rpm}$ under different parameters like $\mathrm{pH} 7.5$, fermentation time of $96 \mathrm{~h}$, temperature of $30{ }^{\circ} \mathrm{C}$, aeration rate of $1.0 \mathrm{vvm}$ and glucose concentration of $90 \mathrm{~g} / \mathrm{l}$ were investigated to find out the optimum agitation rate by immobilized cells of C. glutamicum ATCC and MH 20-22 B. From Table 9 we can observe that maximum L-lysine concentration is $30.17 \pm 0.19 \mathrm{~g} / \mathrm{l}$ and biomass is $16.97 \pm 0.19 \mathrm{~g} / \mathrm{l}$ at $200 \mathrm{rpm}$. Therefore optimum agitation rate for high L-lysine production is $200 \mathrm{rpm}$ for immobilized cells of C. glutamicum ATCC 13032. Shah et al. (2002) investigated about influence of agitation rate and reported that the optimum range is between 50 and $300 \mathrm{rpm}$ (Shah et al. 2002). Similar studies were carried out by Razak and Viswanath for biotechnological production of L-lysine by stirred tank bioreactor and they reported that optimum agitation rate of L-lysine production is $200 \mathrm{rpm}$ for C. glutamicum MH 20-22 B (Razak and viswanath 2014). Table 10 shows that the highest lysine yield is $31.58 \pm 0.24(\mathrm{~g} / \mathrm{l})$ and maximum biomass concentration is $17.73 \pm 0.18$ (g/l) for immobilized cells of $C$. glutamicum $\mathrm{MH} 20-22 \mathrm{~B}$ at $200 \mathrm{rpm}$.

\section{Conclusions}

In order to improve the production rate of L-lysine, immobilized cell of C. glutamicum ATCC 13032 and MH 20-22 B were analyzed under various physical and chemical process parameters. Taken together, the results of this study indicated that the optimum values of fermentation time, $\mathrm{pH}$, temperature, glucose concentration, airflow rate 
Table 11 Optimized fermentation parameters for immobilized cells of C. glutamicum C. glutamicum ATCC 1303 and MH 20-22 B

\begin{tabular}{lll}
\hline Fermentation conditions & $\begin{array}{l}\text { Immobilized cells } \\
\text { of } \text {. glutamicum } \\
\text { ATCC 13032 }\end{array}$ & $\begin{array}{l}\text { Immobilized cells } \\
\text { of } C \text {. glutamicum } \\
\text { MH 20-22 B }\end{array}$ \\
\hline Fermentation time (h) & 96 & 96 \\
$\mathrm{pH}$ & 7.5 & 7.5 \\
Temperature $\left({ }^{\circ} \mathrm{C}\right)$ & 30 & 30 \\
Glucose concentration $(\mathrm{g} / \mathrm{l})$ & 90 & 90 \\
Airflow rate $(\mathrm{vvm})$ & 1.0 & 1.0 \\
Aeration rate (rpm) & 200 & 200 \\
\hline
\end{tabular}

and aeration rate were $96 \mathrm{~h}, 7.5,30^{\circ} \mathrm{C}, 90 \mathrm{~g} / \mathrm{l}, 1.0 \mathrm{vvm}$ and $200 \mathrm{rpm}$ respectively for immobilized cells (Table 11). From the results obtained from this investigation we conclude that the immobilized cells of the $C$. glutamicum mutant MH 20-22 B produced more lysine compared to the wild type $C$. glutamicum ATCC 13032. The present study reveals that the bioreactor studies for the optimization of different physical and chemical parameters for the maximum production of L-lysine can also be extended to the fluidized bed bioreactor. The advantage of the bioprocess based on immobilized cells include enhancing microbial cell stability, allowing continuous process operation and avoiding the biomass-liquid separation requirement. Immobilizing $C$. glutamicum cells is one of the bioprocess engineering approaches for improving biotechnological production of L-Lysine. Based on the present studies further studies may be carried out by genetically modified strains to evaluate physical and chemical process parameters for L-lysine production.

Acknowledgments Authors are grateful to NATCO for all their encouragement in fermentation studies. Authors want to thank anonymous reviewers for their valuable suggestions to improve this paper.

Conflict of interests We are declaring that there is no conflict of interests regarding the publication of this article.

Open Access This article is distributed under the terms of the Creative Commons Attribution License which permits any use, distribution, and reproduction in any medium, provided the original author(s) and the source are credited.

\section{References}

Amin GA, Al-Talhi A (2007) Production of L-Glutamic acid by immobilized cell reactor of the bacterium Corynebacterium glutamicum entrapped into carrageenan gel beads. World Appl Sci J 2(1):62-67

Anastassiadis S (2007) L-Lysine fermentation. Recent Pat Biotechnol $1(1): 11-24$
Araki K, Kato F, Aral Y, Nakayama K (1974) Histidine production by auxotrophic histidine analog-resistant mutants of Corynebacterium glutamicum. Agri Biol Chem 38:837

Becker MJ (1982) Product biosynthesis in continuous fermentation. Folia Microbiol 27:315-318

Bercovici D, Fuller MF (2007) Industrial amino acids in non ruminant animal nutrition. In: Wallace RJ, Chesson A (eds) Biotechnology in animal feeds and animal feeding. Wiley-VCH, Weinheim. doi:10.1002/9783527615353.ch6

Chinard FP (1952) Photometric estimation of proline and ormithine. J Biol Chem 199:91-95

Eggeling L (2007) L-Serine and glycine. In: Wendisch VF (ed) Amino acid biosynthesis pathway, regulation and metabolic engineering, vol 5. Springer, Berlin, p 259-272

Guillout S, Rodal AA, Lessard PA, Sinskey AJ (2002) Methods for producing L-isoleucine. USA patent (US 6451564)

Hadj Sassi A, Fauvart L, Deschamps AM, Lebeault JM (1988) Fed batch production of L-Lysine by Corynebacterium glutamicum. Biochem Eng J 1:85-90

Hilliger M, Haenel F, Menz J (1984) Influence of temperature on growth and L-Lysine formation in Corynebacterium glutamicum. J Appl Microbiol 24:437-441

Hirose Y, Shibai H (1985) L-Glutamic acid fermentation. Compreh Biotechnol 3:595-600

Ikeda M (2006) Towards bacterial strains overproducing L-tryptophan and other aromatics by metabolic engineering. Appl Microbiol Biotechnol 69:615-626

Ikeda M, Katsumata R (1992) Metabolic engineering to produce tyrosine or phenylalanine in a tryptophan producing Corynebacterium glutamicum strain. Appl Env Microbiol 58:781-785

Jetty A, Gangagni Rao A, Sarva Rao B, Madhavi G, Ramakrishna SV (2005) Comparative studies of ALR and FBR for Streptomycin production by immobilized cells of Streptomyces Sp. Chem Biochem Eng 19:179-184

Kalinowski J, Bathe B, Bartels D, Bischoff N, Bott M, Burkovski A, Dusch N, Eggeling L, Eikmanns BJ, Gaigalat L (2003) The complete Corynebacterium glutamicum ATCC 13032 genome sequence and its impact on the production of aspartate derived amino acids and vitamins. J Biotechnol 104:5-25

Kase H, Nakayama K (1974) Studies on L-threonine fermentation, mechanism of L-threonine and L-lysine production by analogresistant mutants of Corynebacterium glutamicum. Agric Biol Chem 38:993-1000

Kinoshita S, Udaka S, Shimono M (1957) Amino acid fermentation I. Production of L-glutamic acid by various microorganism. J Gen Appl Microbiol 3:193-205

Kinoshita S, Nakayama K, Akita S (1958) Taxonomical study of glutamic acid accumulating bacteria, Micrococcus glutamicus. Agri Chem Soc Jpn 22:176

Leuchtenberger W, Huthmacher K, Drauz K (2005) Biotechnological production of amino acids and derivatives: current status and prospects. Appl Microbiol Biotechnol 69(1):1-8

Marek PJ, Kierstan M, Coughlan MP (1985) Immobilized cells and enzymes. Practical approaches UK, Ireland press limited 43-44

Michalski HJ, Krzystek L, Blazczyk R, Jamroz T, Wieczorek A (1984) The effect of mean residence time and aeration intensity on the L-Lysine production in a continuous culture. In: Third Europian congress on biotechnology, Verlag Chemie, Weinheim, 2, p 527-532

Miller GL (1959) Use of dinitrosalicylic acid reagent for detection of reducing sugar. Ann Chem 31:427-431

Morris DL (1948) Microbial physiology. Wiley, New York 161

Nakayama HV, Araki K (1973). Process for producing L-lysine, US patent (3708395)

Neish AC (1952) Analytical methods for bacterial fermentation. Manual, published by the National Research Council of Canada 
Patek M (2007) Branched chain amino acids biosynthesis pathways, regulation and metabolic engineering. Springer, Heidelberg 778

Pfefferle W, Moeckel B, Bathe B, Marx A (2003) Biotechnological manufacture of L-Lysine. In Scheper T (ed) Advances in biochemical engineering/biotechnology, vol 79. Springer, Berlin, p 59

Razak MA, Viswanath B (2014) Optimization of fermentation upstream parameters and immobilization of Corynebacterium glutamicum MH 20-22 B cells to enhance the production of LLysine. 3 Biotech. doi 10.1007/s13205-014-0252-7

Ruklisha M, Paegle L, Denina I (2007) L-Valine biosynthesis during batch and fed batch cultivations of Corynebacterium glutamicum: relationship between changes and bacterial growth rate and intracellular metabolism. Prog Biochem 42:634-640

Shah AH, Hameed A, Khan GM (2002) Fermentative production of Llysine, bacterial fermentation. J Med Sci 2:152-157

Shiio I (1990) Threonine production by dihydrodipicolinate synthasedefective mutants of Brevibacterium flavum. Biotechnol Adv 8:97-103
Shiio I, Toride Y, Yokota A, Sugimoto S, Kawamura K (1991) Process for the production of L-threonine by fermentation, USA Patent (5077207)

Tryfona T, Bustard MT (2005) Fermentation production of lysine by Corynebacterium glutamicum: transmembrane transport and metabolite flux analysis. Process Biochem 40(2):499-508

Udaka S (1960) Screening method for microorganisms accumulating metabolites and its use in the isolation of Micrococcus glutamicus. J Bacteriol 79:754-755

Wang JS, Kuo YC, Chang CC, Liu YT (1991) Optimization of culture conditions of L-lysine fermentation by Brevibacterium species. Nat Biotechnol 68:154-159

Wendisch VF, Bott M (2005) In Handbook of Corynebacterium glutamicum, CRC Press. Taylor \& Francis, Boca Raton, pp 377-396 